MINERALOGIA, 48, No 1-4: 127-143 (2017)

DE DE GRUYTER OPEN

DOI: $10.1515 /$ mipo-2017-0016

www.Mineralogia.pl

MINERALOGICAL SOCIETY OF POLAND

POLSKIE TOWARZYSTWO MINERALOGICZNE

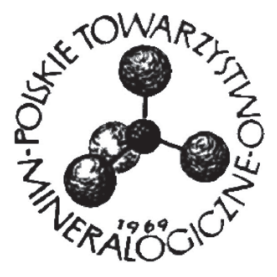

Original paper

\title{
Assessment of heavy metals inactivation in contaminated soil by coal fly and bottom ashes
}

\author{
Jean DIATTA ${ }^{1 *}$, Edward FOJCIK ${ }^{2}$, Leszek DROBEK ${ }^{3}$, Tomasz SPIŻEWSKI ${ }^{4}$, \\ Włodzimierz KRZESIŃSKI ${ }^{4}$ \\ ${ }^{I}$ Poznan University of Life Sciences, Department of Agricultural Chemistry and Environmental Biogeochemistry, \\ ul. Wojska Polskiego 71F, 60-625, Poznań, Poland \\ ${ }^{2}$ SEGO Sp. z o.o., ul. O. Kolberga 65, 44-251, Rybnik, Poland \\ ${ }^{3}$ Central Mining Institute, Department of Environment Monitoring, Plac Gwarków 1, 40-166 \\ Katowice, Poland \\ ${ }^{4}$ Poznan University of Life Science, Department of Vegetable Crops, Poznań University of Life Sciences, Poznań, \\ Poland \\ * Corresponding author \\ e-mail: jeandiatta63@yahoo.com
}

Received: May 2, 2017

Received in revised form: August 30, 2017

Accepted: August 31, 2017

Available online: September 30, 2017

\begin{abstract}
The study compared coal fly and bottom ashes for their ability to inactivate metals and lead to soil remediation. Soil was artificially contaminated with $\mathrm{Cu}, \mathrm{Zn}, \mathrm{Pb}$ and $\mathrm{Cd}$ at five degrees. Next, both ashes were added at five rates: $0,0.5,1.0,1.5$ and $2.0 \%$ and all treatments incubated. Data showed that for moderately contaminated soils, ash rates of $0.5-1.0 \%$ were efficient from 40 to $70 \%$ for $\mathrm{Zn}$ and $\mathrm{Cd}$, and raised markedly to between 70 and $93 \%$ for $\mathrm{Cu}$ and $\mathrm{Pb}$. For extremely contaminated soils, the rates of ashes at 1.0, 1.5 and $2 \%$ were much more efficient $(60-80 \%)$. The use of fly and bottom ashes for metal inactivation and soil remediation should give greater consideration to the effect of $\mathrm{pH}$ and the type of heavy metals than the content $\mathrm{SiO}_{2}$ and $\mathrm{Al}_{2} \mathrm{O}_{3}$. Fly ash displayed superior inactivation and remediation effects to the bottom ash.
\end{abstract}

Key-words: Fly ash, bottom ash, soil, heavy metals, inactivation, remediation 


\section{Introduction}

The sources of contamination in anthropogenic areas are diverse and involve mineral as well as organic contaminants. The effect of these compounds on the flora and fauna is multidimensional and often complex to evaluate. Organic contaminants are generally accepted to undergo microbiological breakdown, but mineral ones, specifically heavy metals, may affect the environment for long periods since they are not biodegradable. Soils and their heterogenic nature (mineral and organic colloids) create in many cases favorable conditions for the mitigation of the harmful effects of heavy metals (McBride et al. 1997; Mench et al. 1998; Basta, McGowen 2004). This process may last for extended periods of time estimated at decades, hundreds or even thousands of years, depending on the soil conditions and the concentrations of anthropogenic heavy metals (Sparks 1995).

Due to the natural capacity of soils to neutralize, i.e. sorb and retain metallic elements that may be elevated under high pollution, any additional incorporation into the soil of mineral components acting as sorbents is recommended. This practice is intentionally used for limiting metal mobility and for transfer to the biota, as well as uncontaminated environmental components. Next, the role of the soil $\mathrm{pH}$ should be stressed, which strictly controls heavy metal bioavailability (Bradshaw 2000; Diatta et al. 2004, Diatta et al. 2012) as well as microbial activity (Schutter, Fuhrmann 2001). It has a dominant effect on the solubility, and therefore the availability and potential phytotoxicity of ions (Barrow 1999). Since low $\mathrm{pH}$ is responsible for the emergence of free metal cations and protonated anions, high $\mathrm{pH}$ therefore favors the formation of carbonates or hydroxyl complexes (Gupta et al. 2000). The concentration of metal cations in the soil solution increases with an increase in acidity (Rengel 2001), and the geochemical process may be reported as follows: soil- $\mathrm{M}^{n^{+}}+n \mathrm{H}^{+} \leftrightarrow \mathrm{M}^{n+}+$ soil- $\mathrm{H}_{\mathrm{n}}^{+}$; where $\mathrm{M}$ represents a metal and $\mathrm{H}$, the hydrogen.

Sometimes, the solubility of metals at high $\mathrm{pH}$ may be greater than expected from the simple $\mathrm{pH}$ relationships of the solubility of the relevant soil minerals, due to the formation of metal - organic ligand complexes (Sumner et al. 1991; Fotovat et al. 1997; Diatta et al. 2009).

In general, the toxic effects of heavy metals are strongly controlled by $\mathrm{pH}$ (Ibekwe et al. 1997; Basta, McGowen 2004), although some studies have also emphasized the equal importance of metal loading rates (Diatta et al. 2007). One complication in predicting metal bioavailability is that $\mathrm{pH}$ controls not only the free activity of the metal, but also the speciation of other ions in the soil solution and their potential for forming ion complexes with soil organic matter and organic acids (Vacha et al. 2000).

Several remediation methods have been applied under in-situ (Matsi, Keramidas 1999; McGowen 2000; Oste et al. 2002) as well as ex-situ (Tandy et al. 2004; Diatta, Chudzinska 2009) conditions to soils anthropogenically contaminated with various contaminants. Additives, among others zeolites (Querol et al. 2005) and clay minerals (Lombi et al. 2003), were also applied to soils for this purpose. Such mineral/chemical treatment results most often in heavy metal stabilization/immobilization and is one of the most widely used practices for decreasing the concentrations of soluble and mobile contaminants. Next, processes such as sorption and precipitation strongly limit the flow and migration of contaminants to the deepest soil layers and thus reduce the threat of groundwater pollution (Singh, Shea 1999). These amendments most often contain liming agents, trace element 
$(\mathrm{Fe} / \mathrm{Mn})$ oxyhydroxides, and organic materials such as biosolids, sludge or composts (Krebs et al. 1999; Adriano et al. 2004; Mench et al. 2007; Kumpiene et al. 2008).

Large scale use of coal and biolite in industrial power generation gives rise to significant quantities of combustion by-products (wastes), and particularly ashes, from which important "hard won" end-use markets have been established (Gajda et al. 2002; Xiao et al. 2011; Sarbak et al. 2012; Ramme, Tharaniyil 2013; Szymańska 2013). The concept of the Circular Economy Package (ec.europa.eu/environment/circular-economy) assumes less or no standing over of by-products, particularly at the level of industrial production systems. The recycling of by-products should be planned at the start of the production, and not when they are being left on heaps. This concerns fly and bottom ashes originating from the combustion of coal and biolites. Their chemical composition makes then attractive for several goals, including the amelioration of soils and inactivation of heavy metals (Mohapatra, Rao 2001; Antonkiewicz 2007; Właśniewski 2009; Sarbak et al. 2012; Hycnar et al. 2014; Gluzińska et al. 2016). They consist primarily of calcium oxide $(\mathrm{CaO})$, anhydrite calcium sulfate $\left(\mathrm{CaSO}_{4}\right)$, and calcinated clay materials and quartz.

Environmental regulations in force have been actively initiating the recycling of these wastes (Hycnar et al. 2014) and their application for mitigating the dispersion of metal contaminants in the environment. Their progressive and extensive use relies on their largescale availability, low price and effects on the soil $\mathrm{pH}$, which significantly alters the buffering properties. The metal inactivation as well as remediation efficiency of fly and bottom ashes is also related to the physical characteristics of the particles (Scotti et al. 1999; Mench et al. 2007). The powdered form increases the surface contact with soil colloids and burdened heavy metals, hence ensuring the maximum reactivity. The latter one is activated by the strongly alkaline (high content of free $\mathrm{CaO}$ ) reaction of ashes $(\mathrm{pH} 11$ 13).

The general aim of the current study was to compare the efficiency of fly and bottom ashes originating from coal combustion on a soil artificially contaminated by different levels of $\mathrm{Cu}, \mathrm{Zn}, \mathrm{Pb}$ and $\mathrm{Cd}$. Next, the study explored the heavy metals' inactivation process as well as the remediation capacity of these ashes on the chemical properties of soils, which are decisive for any phytoremediation goals. The specific purpose was to evaluate the relationship between the rates of both ashes and the degree of soil contamination, as well as the type of heavy metal. Recommendations for the use of fly and bottom ashes are outlined.

\section{Materials and methods}

\subsection{Characteristics of the fly and bottom ashes}

Ashes were made available from the Rybnik Power Station (Poland) and tested primarily for some basic parameters. They were analyzed for the content of $\mathrm{CaO}, \mathrm{SiO}_{2}$ and $\mathrm{Al}_{2} \mathrm{O}_{3}$ (Table 1) by using the roentgen fluorescence spectrometry method with wave dispersion. Next, $\mathrm{pH}$ was assessed potentiometrically in an aqueous slurry at the ratio 1:2.5 (Polish Standard 1994), whereas the electrical conductivity (EC) as well as total dissolved solids (TDS), were determined conductometrically at the ratio 1:5 (Rhoades 1996). The obtained data are reported in Table 2 . 
Total content of $\mathrm{CaO}, \mathrm{SiO}_{2}$ and $\mathrm{Al}_{2} \mathrm{O}_{3}$ of investigated ashes

\begin{tabular}{lllll}
\hline \multirow{2}{*}{ Ashes } & $\begin{array}{l}\mathrm{CaO} \\
\%\end{array}$ & $\mathrm{SiO}_{2}$ & $\mathrm{Al}_{2} \mathrm{O}_{3}$ & $\mathrm{CaO} /\left(\mathrm{SiO}_{2}+\mathrm{Al}_{2} \mathrm{O}_{3}\right)$ \\
\cline { 2 - 4 } Fly ash & 16.3 & 36.3 & 18.6 & 0.30 \\
Bottom ash & 6.7 & 55.8 & 21.8 & 0.09 \\
\hline
\end{tabular}

TABLE 2

Reaction ( $\mathrm{pH}$ ), electrical conductivity (EC), total dissolved solids (TDS) and specific surface area (SSA) of investigated ashes

\begin{tabular}{lllllll}
\hline \multirow{2}{*}{ Ashes } & \multirow{2}{*}{$\mathrm{pH}_{(\mathrm{H} 2 \mathrm{O})}$} & $\mathrm{EC}_{5}$ & \multicolumn{3}{l}{$\mathrm{TDS}$} & \multicolumn{3}{l}{ Specific surface area (SSA) $\left(\mathrm{m}^{2} \mathrm{~g}^{-1}\right)$} \\
& $\left(\mu \mathrm{S} \mathrm{cm}^{-1}\right)$ & $\left(\mathrm{mg} \mathrm{dm}^{-3}\right)$ & Total & External & Internal \\
\hline Fly ash & 12.4 & 7720 & 3850 & 6.82 & 0.56 & 6.26 \\
Bottom ash & 12.2 & 2860 & 1427 & 4.37 & 0.08 & 4.11 \\
\hline
\end{tabular}

Since heavy metals' sorption as well as retention could be expected to emerge after the application of ashes, the latter ones were submitted to the determination of the specific surface area (SSA) by using the Ethylene Glycol Monoethyl Ether (EGME) method (Carter et al. 1986). A similar analysis was also performed for the soil sample. For the determination of the external surface area (Brunauer, Emmett and Teller [BET] 1938), ashes and the soil sample were dried at $120^{\circ} \mathrm{C}$ for $10-12 \mathrm{~h}$ and outgassed. The measurement of the adsorption of $\mathrm{N}_{2}$ gas (the adsorbate) at $77.35 \mathrm{~K}$ was performed by using a Micrometics ASAP 2010 on the basis of a linearized five-point isotherm (Gregg, Singh 1967; de Jong, 1999). The values are listed in Table 2.

Total content of $\mathrm{Cu}, \mathrm{Zn}, \mathrm{Pb}$ and $\mathrm{Cd}$ in the ashes were determined according to the ISO 11466 procedure (International Standard 1995). Air-dried ash samples $(1 \pm 0.001 \mathrm{~g})$ were weighed into a glass Erlenmeyer flask and $15 \mathrm{~cm}^{3}$ of aqua regia $(1: 3$ concentrated nitric acid and hydrochloric acid) were added. Next, the mixture was heated at $140^{\circ} \mathrm{C}$ under reflux for $2 \mathrm{~h}$ on a sand-bath. After cooling, it was filtered through filter paper into $15 \mathrm{~cm}^{3}$ test tubes and filled to the mark with bi-distilled water. Concentrations of $\mathrm{Cu}, \mathrm{Zn}, \mathrm{Pb}, \mathrm{Cd}$ and $\mathrm{Ca}$ were determined by atomic absorption spectrometry (AAS) (Varian 250 Spectra Plus). Relative standard deviation (RSD) was calculated from the pooled data for the applied methods. In the precision test, the average RSD percentage for all metal ranged from 0.55 to $7.55 \%$. The accuracy of the chemical tests was determined using a reference material (Estuarine sediment 277 CRM, certified by the Bureau Community of Reference (BCR), Brussels, Belgium). A summary of the data is reported in Table 3. 
Total content of $\mathrm{Cu}, \mathrm{Zn}, \mathrm{Pb}$, and $\mathrm{Cd}$ of investigated ashes

\begin{tabular}{lllll}
\hline Ashes & $\mathrm{Cu}$ & $\mathrm{Zn}$ & $\mathrm{Pb}$ & $\mathrm{Cd}$ \\
\hline Fly ash & $\mathrm{mg} \mathrm{kg}^{-1}$ & & & \\
Bottom ash & 104 & 460 & 160 & 2.0 \\
\hline
\end{tabular}

\subsection{Experimental design for evaluating the inactivation and remediation properties of the fly and bottom ashes}

\subsubsection{Soil and contamination process}

The soil used for the current study was collected from an experimental agricultural farm (Swadzim) belonging to the Poznan University of Life Sciences (Poznan, Poland). The site has for many years been subjected to plant testing consisting of cereals, potatoes, sugar beets and even grasses, at different rotations. Only mineral fertilizers were applied for supporting adequate plant growth. Some properties are listed in Table 4. Next, the soil was artificially contaminated with $\mathrm{CuSO}_{4}, \mathrm{ZnSO}_{4}, \mathrm{~Pb}\left(\mathrm{NO}_{3}\right)_{2}$ and $\mathrm{CdCl}_{2}$, respectively, which were added altogether to form five (5) respective treatments (0, I, II, III, IV), each consisting of $6 \mathrm{~kg}$. The levels of $\mathrm{Cu}, \mathrm{Zn}, \mathrm{Pb}$ and $\mathrm{Cd}$ were scheduled according to the threshold contamination degree (Table 5) reported by Kabata-Pendias et al. (1993). These treatments (soils and respective levels of heavy metals) were incubated for seven (7) months at $20^{\circ} \mathrm{C}$ and $75 \%$ water holding capacity (WHC) of the soils. After the incubation process, soils in the treatments were additionally analyzed for total content of the added heavy metals. The results are listed in Table 6. The natural capacity of the soil for inactivating metals was tested for the potentially mobile heavy-metal fractions, which were extracted by $0.010 \mathrm{~mol} \mathrm{CaCl}_{2} \mathrm{dm}^{-3}$. This test was performed on soil samples collected from the artificially contaminated soils (after 7 months of incubation) just before the incorporation of fly and bottom ashes. Data from this test are reported in Table 7.

\subsubsection{Rating of fly and bottom ashes versus treatments}

The weight of heavy metal contaminated soils (treatments) amounted to $1.0 \mathrm{~kg}$, which was placed into experimental pots. Then, fly and bottom ashes were added to the treatments at the rates of $0,0.50,1.0,1.5$ and $2.0 \%$ (dry weight basis) and mixed thoroughly. The incorporated amounts corresponded to the rates of $0,15,30,45$ and 60 tons of both ashes per 1 hectare. Treatments were next incubated for four (4) months at $20^{\circ} \mathrm{C}$ and $75 \% \mathrm{WHC}$. At the end of the incubation, samples were collected for performing chemical tests $(\mathrm{pH}$, potentially mobile forms of $\mathrm{Cu}, \mathrm{Zn}, \mathrm{Pb}$ and $\mathrm{Cd}$ ), enabling the evaluation of the inactivation and remediation properties of the ashes. 


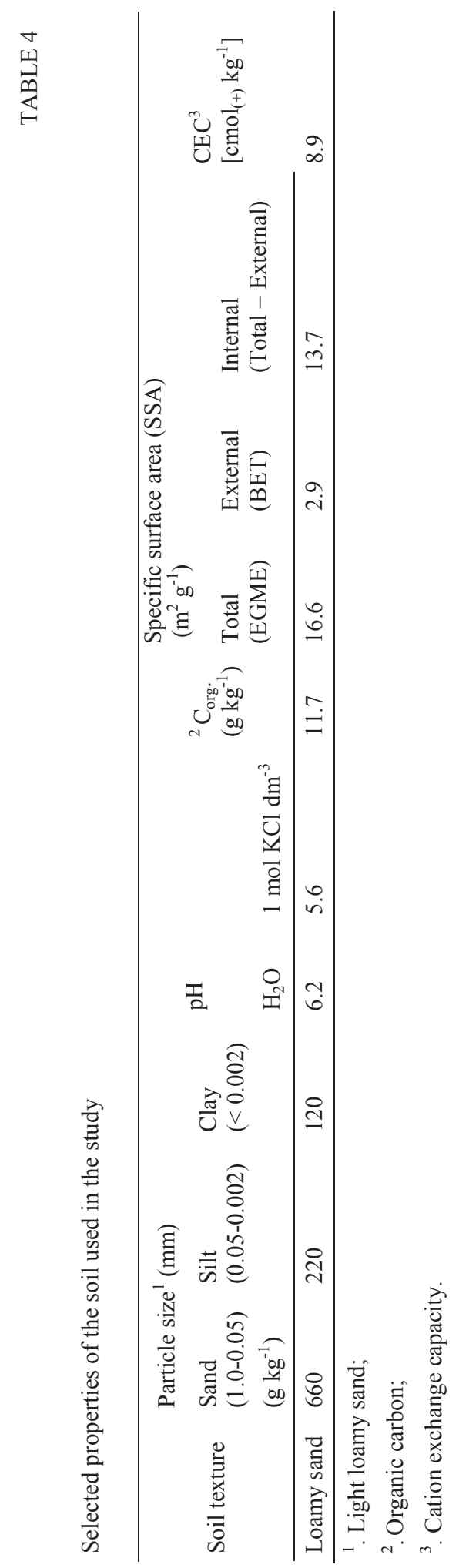


Degrees of soil contamination according to Kabata-Pendias et al. (1993)

\begin{tabular}{|c|c|c|c|c|c|}
\hline \multirow{3}{*}{ Metal } & \multicolumn{5}{|c|}{ Degrees of soil contamination } \\
\hline & 0 & I & II & III & IV \\
\hline & \multicolumn{5}{|c|}{$\mathrm{mg} \mathrm{kg}^{-1}$} \\
\hline $\mathrm{Cu}$ & 25 & 250 & 400 & 500 & 2500 \\
\hline $\mathrm{Zn}$ & 70 & 200 & 500 & 1500 & 5000 \\
\hline $\mathrm{Pb}$ & 50 & 100 & 250 & 1000 & 5000 \\
\hline $\mathrm{Cd}$ & 0.5 & 7.5 & 15 & 25 & 50 \\
\hline
\end{tabular}

TABLE 6

Total content of $\mathrm{Cu}, \mathrm{Zn}, \mathrm{Pb}$ and $\mathrm{Cd}$ in the artificially contaminated treatments after seven (7) months of incubation

\begin{tabular}{lllll}
\hline Soil/Treatment & $\begin{array}{l}\mathrm{Cu} \\
\mathrm{mg} \mathrm{kg}^{-1}\end{array}$ & $\mathrm{Zn}$ & $\mathrm{Pb}$ & $\mathrm{Cd}$ \\
\hline Control & 7.9 & 77.7 & 11.7 & 0.75 \\
Treatment I & 150.7 & 229.9 & 85.8 & 8.8 \\
Treatment II & 266.9 & 475.9 & 332.2 & 18.6 \\
Treatment III & 535.3 & 1844.2 & 1329.2 & 39.5 \\
Treatment IV & 2308.8 & 5527.2 & 5314.4 & 69.8 \\
\hline
\end{tabular}

TABLE 7

Potentially mobile heavy metal fractions (extracted by $0.010 \mathrm{~mol} \mathrm{CaCl}_{2} \mathrm{dm}^{-3}$ ) of the artificially contaminated soils before the incorporation of fly and bottom ashes

\begin{tabular}{lllllll}
\hline Treatment & $\begin{array}{l}\mathrm{Cu} \\
\mathrm{mg} \mathrm{kg}^{-1}\end{array}$ & $\mathrm{Zn}$ & $\mathrm{Pb}$ & $\mathrm{Cd}$ & $\begin{array}{l}\mathrm{pH} \\
\mathrm{H}_{2} \mathrm{O}\end{array}$ & $1 \mathrm{~mol} \mathrm{KCl} \mathrm{dm}^{-3}$ \\
\hline $\mathrm{O}$ & 0.5 & 25.2 & 0.39 & 0.42 & 6.20 & 5.60 \\
$\mathrm{I}$ & 1.2 & 44.1 & 0.46 & 1.6 & 6.10 & 5.50 \\
$\mathrm{II}$ & 1.9 & 95.0 & 0.51 & 3.2 & 5.80 & 5.40 \\
$\mathrm{III}$ & 4.6 & 490.1 & 0.56 & 9.8 & 5.60 & 5.20 \\
$\mathrm{IV}$ & 372.0 & 1243.3 & 47.7 & 45.6 & 5.50 & 4.80 \\
\hline
\end{tabular}




\subsubsection{Testing for $\mathrm{pH}$ and potentially mobile forms of $\mathrm{Cu}, \mathrm{Zn}, \mathrm{Pb}$ and $\mathrm{Cd}$}

Samples collected from the respective treatments were subjected to chemical tests by using $0.01 \mathrm{~mol} \mathrm{CaCl}_{2} \mathrm{dm}^{-3}$ at the ratio 1:5. Then, $5 \mathrm{~g}$ was weighed into PE extraction tubes and $25 \mathrm{~cm}^{3}$ of the extractant added. The slurry was mixed at $50 \mathrm{rpm}$ for $1 \mathrm{~h}$, left to equilibrate for $5 \mathrm{~h}$ and the decant filtered. Filtrates were determined for $\mathrm{pH}$ potentiometrically (Fig. 1), and $\mathrm{Cu}, \mathrm{Zn}, \mathrm{Pb}$ and $\mathrm{Cd}$ by flame atomic absorption spectrometry (FAAS) (Fig. 2 - 4).
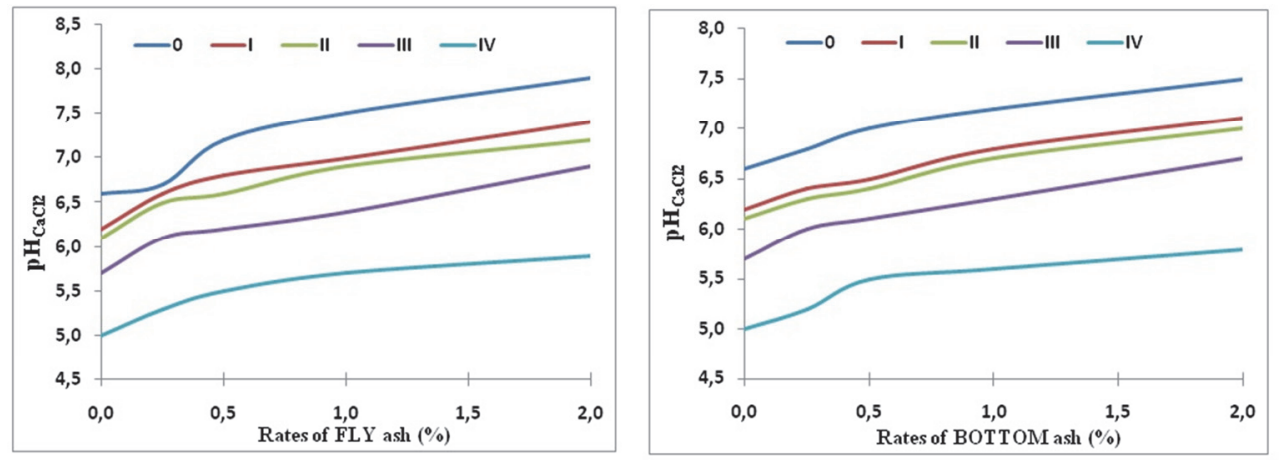

Fig. 1. Changes in $\mathrm{pH}_{\mathrm{CaCl} 2}$, as induced by fly and bottom ashes rates $(0,0.5,1.0,1.5$ and $2.0 \%)$ and the degree of contamination by $\mathrm{Cu}, \mathrm{Zn}, \mathrm{Pb}$ and $\mathrm{Cd}(0, \mathrm{I}$, II, III, and IV)
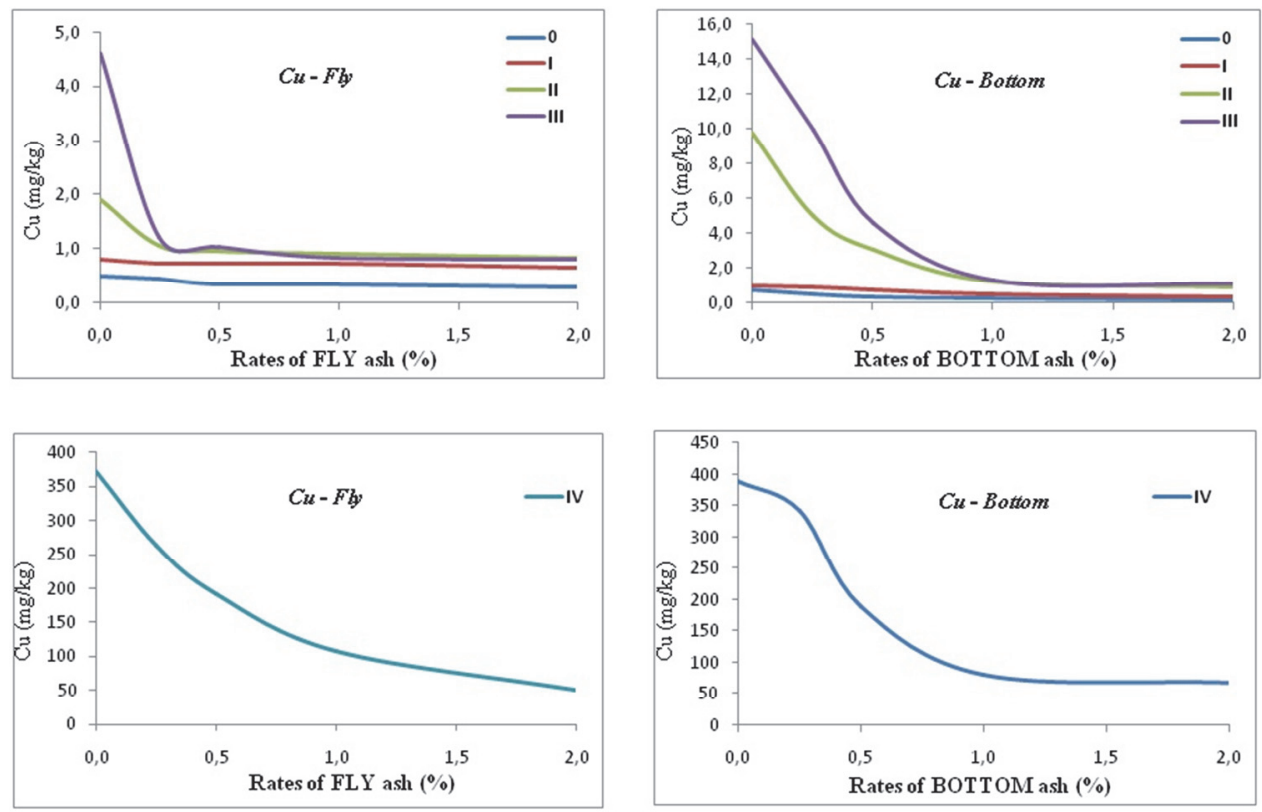

Fig. 2. Variations in the concentrations of potentially mobile $\mathrm{Cu}$, induced by rates of FLY and BOTTOM ashes and the degrees of soil contamination 
The overall calculations, simplified statistical description as well as graphical presentation of the results were performed using the $\mathrm{Excel}^{\odot}$ sheet facilities.
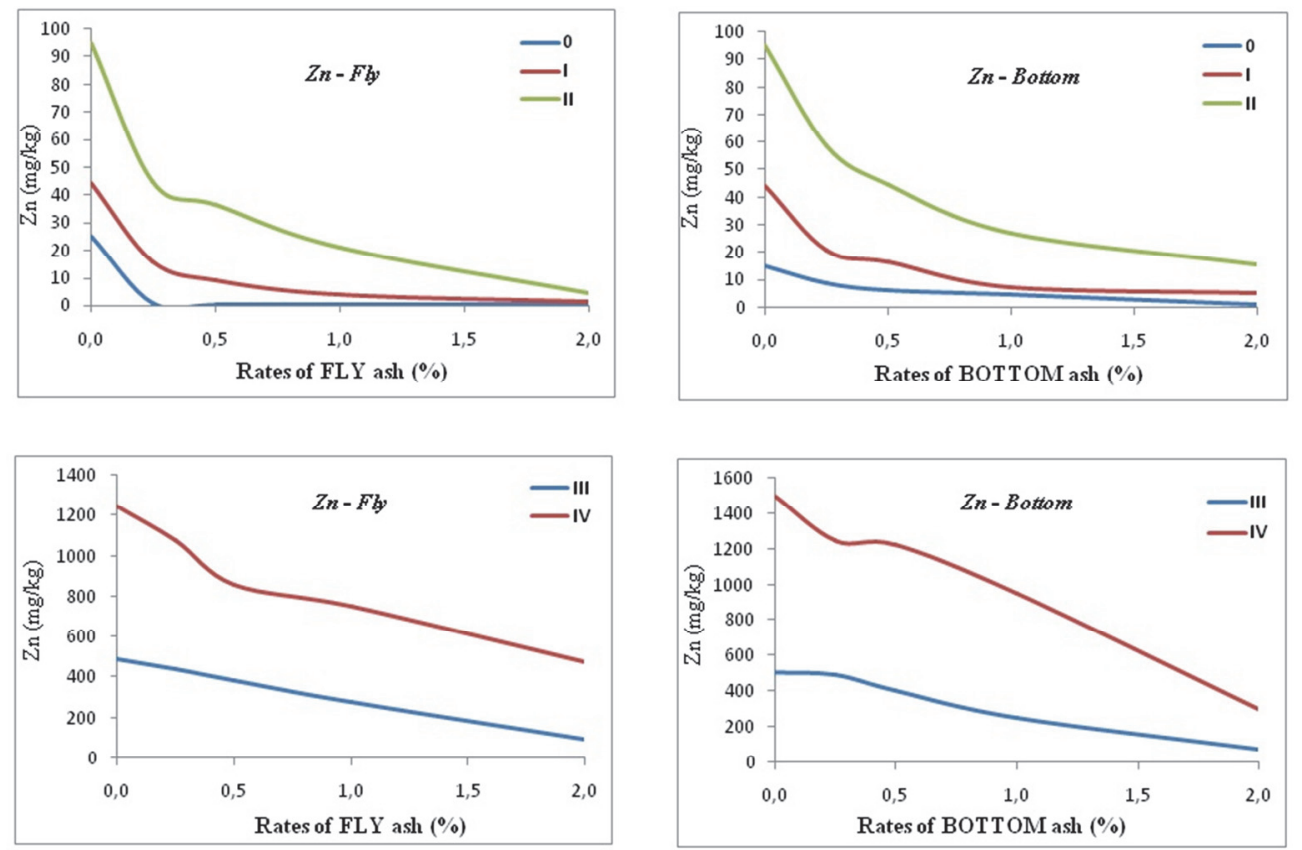

Fig. 3. Variations in the concentrations of potentially mobile $\mathrm{Zn}$, induced by rates of FLY and BOTTOM ashes and the degrees of soil contamination
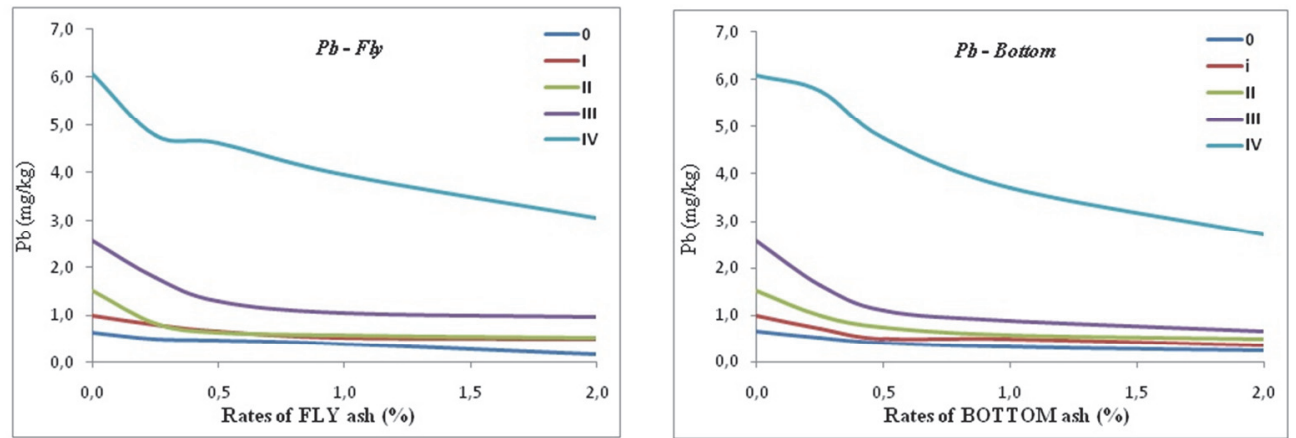

Fig. 4. Variations in the concentrations of potentially mobile $\mathrm{Pb}$, induced by rates of FLY and BOTTOM ashes and the degrees of soil contamination 


\section{Results}

\subsection{Fly and bottom ashes characteristics}

Data reported in Table 1 revealed the prevailing content of $\mathrm{CaO}$ in the fly ash $(16.3 \%)$ as compared to the bottom ash (6.7\%). These characteristics of the bottom ash could be considered as favorable for developing a higher reactive surface, due to the allophanic properties of $\mathrm{Si}$ and $\mathrm{Al}$ oxides (i.e. $\mathrm{SiO}_{2}, \mathrm{Al}_{2} \mathrm{O}_{3}$ ) as the prevailing chemical constituents. But the values of the specific surface areas (SSA) as listed in Table 2 are not in line with this statement. Both ashes were characterized by significantly low $\mathrm{SSA}_{\mathrm{EGME}}$ values, amounting to 6.82 and $4.37 \mathrm{~m}^{2} \mathrm{~g}^{-1}$ for the fly and bottom ashes, respectively. On the basis of this parameter, one may assume that the sorption and retention properties should be playing a secondary plan role.

The reactivity of these ashes should be also evaluated throughout the ratio of $\mathrm{CaO}$ to the sum of $\mathrm{SiO}_{2}$ and $\mathrm{Al}_{2} \mathrm{O}_{3}$, being three times higher for the fly ash (0.3) in comparison to the bottom ash. On this basis, it appeared that fly ash will display much stronger ameliorative as well as remediative features. The aqueous $\mathrm{pH}$ of both ashes did not vary enough, since the difference was only 0.2 (Table 2). The alkaline character of both ashes (12.4 for the fly ash and 12.2 for the bottom ash) is indicative of the occurrence of $\mathrm{CaO}$ and derivatives, which generally hydrolyze and generate significant hydroxide ions $\left(\mathrm{OH}^{-}\right)$. On the other hand, the EC, particularly for the fly ash, indicated a strong presence of soluble ions and chemical compounds.

The content of heavy metals is one of the most important parameters (out of the concentration of $\mathrm{CaO}$ ) justifying the use of ashes for metal inactivation and simultaneous soil remediation. As reported in Table 3, only the concentrations of zinc $(\mathrm{Zn})$ were found to be high, i.e. 460 and $434 \mathrm{mg} \mathrm{kg}^{-1}$ for the fly and bottom ashes, respectively. In the case of lead $(\mathrm{Pb})$, copper $(\mathrm{Cu})$ and cadmium $(\mathrm{Cd})$, their levels were not in a position to exhibit any threat related to massive incorporation to soil.

\subsection{Soil amelioration potential of the ashes}

The value of the cation exchange capacity $\left[\mathrm{CEC}=8.9 \mathrm{cmol}_{(+)} \mathrm{kg}^{-1}\right]$ of the soil used for the study implies that the buffering properties are relatively weak (Table 4). This is confirmed by the specific surface area $\left(16.6 \mathrm{~m}^{2} \mathrm{~g}^{-1}\right)$, as well as the slightly acidic $\mathrm{pH}$. On the other hand, these characteristics are favorable for evaluating the behavior of artificially incorporated heavy metals (Table $5-6$ ) and next ashes, as sorbents controlling the mobility or immobility of these metals. The rates of the latter ones have been varied in order to outline the real inactivation and remediation potential of the ashes. The efficiency of the whole process was monitored by rating the ashes at $0,0.25,0.50,1.0$ and $2.0 \%$, which corresponded to $0,7.5,15,30$ and 60 tons of both ashes per hectare.

The soil chemical properties altered along with the incorporation of heavy metals (Table 7). These changes were proportional to their rates, according to the degrees of contamination listed as 0 , I, II, III and IV. The most mobile metals were $\mathrm{Zn}$ and $\mathrm{Cd}$, in contrast to the least mobile ones, which were $\mathrm{Cu}$ and particularly $\mathrm{Pb}$. The raise in soil acidification expressed by the decrease of $\mathrm{pH}$ impacted $\mathrm{Zn}$ and $\mathrm{Cd}$ retention to a much 
greater extent, but also $\mathrm{Cu}$ in the case of the highest contamination degree, i.e. treatment IV.

\subsubsection{Reactivity of the ashes $-\mathrm{pH}$ as a master geochemical parameter}

The geochemical effect of fly and bottom ashes on soil $\mathrm{pH}$ is illustrated by Figure 1. As can be observed, the $\mathrm{pH}$ increased gradually along with the rates of the ashes; a much more pronounced response was observed on treatments, where the fly ash was applied. The highest achieved $\mathrm{pH}$ was 8.0 for the fly ash rate, corresponding to $2.0 \%$, i.e. $60 \mathrm{t} \mathrm{ha}^{-1}$. For the same rate, the $\mathrm{pH}$ did not exceed 7.5 in the case of the bottom ash.

The data clearly showed that even at the highest rate of ashes, the uncontaminated soil (i.e. the control) was not alkalized. For the contaminated treatments III and IV, $\mathrm{pH}$ at the same rate varied between 5.5 (treatment IV) and 6.5 (treatment III). If we consider the treatments III and IV as particularly representative for undertaking inactivation and remediation interventions, it should be expected to incorporate higher rates of both ashes, for instance $70 \mathrm{t} \mathrm{ha}^{-1}$ at $\mathrm{pH} 6.5$ (treatment III) or $80 \mathrm{t} \mathrm{ha}^{-1}$ for reaching $\mathrm{pH}$ of approximately 7.5 (treatment IV).

\subsubsection{Inactivation of heavy metals - efficiency of the ashes}

One of the key purposes of the current study was the evaluation of the efficiency of both ashes for immobilizing heavy metals in contaminated soils. Three efficiency ranges may be formulated:

- Contamination degree corresponding to 0 - II

- Ash rates: $0-1 \%$ and $1-2.0 \%$

- Heavy metals: highly and less reactive

For evaluating the potential threat related to heavy metals, a single extraction test was performed in the case of this study by using $0.01 \mathrm{~mol} \mathrm{CaCl} \mathrm{dm}^{-3}$. The extracted heavy metals are designated as the active and simultaneously highly mobile forms of $\mathrm{Cu}, \mathrm{Zn}, \mathrm{Pb}$ and $\mathrm{Cd}$. These forms represent the amount of metals weakly bound or weakly immobilized by the soil without and with incorporated ashes. This is well visualized in Figures 2, 3, 4 and 5, respectively, for $\mathrm{Cu}, \mathrm{Zn}, \mathrm{Pb}$ and $\mathrm{Cd}$.

The evaluation of the processes and mechanisms is based on the assumption that the higher the concentrations of $\mathrm{Cu}, \mathrm{Zn}, \mathrm{Pb}$ and $\mathrm{Cd}$ extracted, the weaker the sorption and inactivation processes. These graphs decidedly show that metal inactivation depended much more on the quality of ashes, the degree of contamination and the type of heavy metals. The latter ones have revealed the following practical pattern:

- for the moderately contaminated treatments I and II, the rates 0.50 and $1.0 \%$ of both ashes were found to be highly efficient for inactivating $\mathrm{Cu}, \mathrm{Zn}, \mathrm{Pb}$ and $\mathrm{Cd}$, with $\mathrm{Pb}$ and $\mathrm{Cu}$ to a greater extent than $\mathrm{Cd}$ and $\mathrm{Zn}$. This efficiency ranged from 40 to $70 \%$ for $\mathrm{Zn}$ and $\mathrm{Cd}$, but raised markedly to between 60 and $93 \%$ for $\mathrm{Cu}$ and $\mathrm{Pb}$, as compared to the control treatment.

- for the extremely contaminated treatments III and IV (the highest contamination degrees), the rates of both ashes, i.e. 1.5 and $2.0 \%$, but particularly $2.0 \%$, were much 
more efficient. The heavy metal inactivation process varied then from nearly 60 to $80 \%$, as compared to the control treatment.
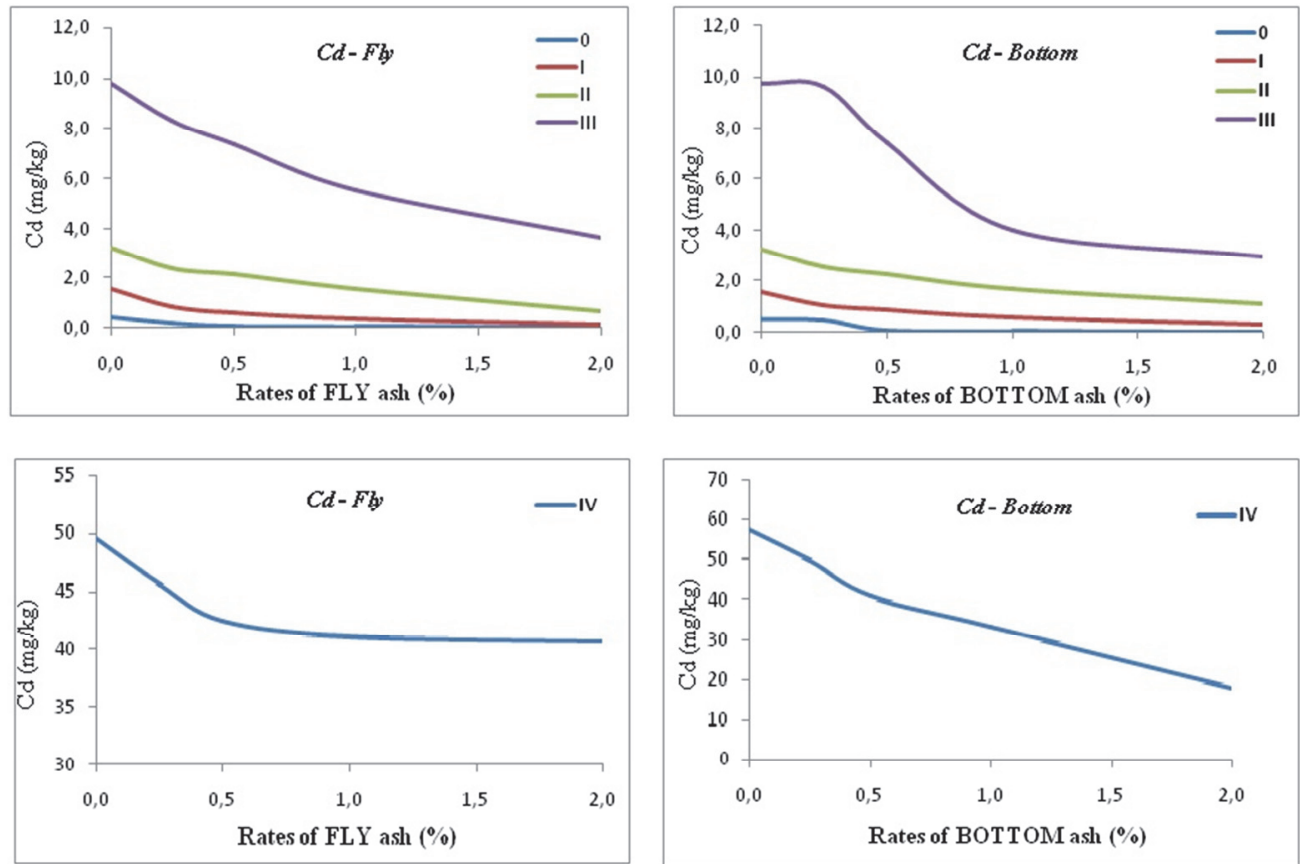

Fig. 5. Variations in the concentrations of potentially mobile Cd, induced by rates of FLY and BOTTOM ashes and the degrees of soil contamination

\section{Discussion}

The physical and chemical characteristics of ashes which basically influence their geochemical reactivity deal with the particle size and the content of $\mathrm{SiO}_{2}, \mathrm{Al}_{2} \mathrm{O}_{3}, \mathrm{Fe}_{2} \mathrm{O}_{3}$ and $\mathrm{CaO}$, respectively. Of these characteristics, only the particle size appears as a standardized parameter, with particle diameter $\varnothing<0.2 \mathrm{~mm}$. It is agreed that ashes with the content of $\mathrm{SiO}_{2}>40 \%, \mathrm{Al}_{2} \mathrm{O}_{3}<30 \%$ are designated as siliceous, with $\mathrm{SiO}_{2}>40 \%, \mathrm{Al}_{2} \mathrm{O}_{3}>30 \%$ as aluminous, and with $\mathrm{SiO}_{2}>30 \%, \mathrm{Al}_{2} \mathrm{O}_{3}<30 \%$ as calcic (Łączny 2002; Gluzińska et al. 2016). The fly ash applied in the current study fulfilled the condition " $\mathrm{SiO}_{2}>30 \%, \mathrm{Al}_{2} \mathrm{O}_{3}<$ $30 \%$ ", meaning that it is basically calcic; whereas the bottom ash fitted the range " $\mathrm{SiO}_{2}>40 \%, \mathrm{Al}_{2} \mathrm{O}_{3}<30 \%$ ", and thus is siliceous. In their study, Terzano et al. (2007) applied a coal fly ash consisting of $48.1 \% \mathrm{SiO}_{2}, 24,6 \% \mathrm{Al}_{2} \mathrm{O}_{3}$, which can be classified as a typically siliceous material. A fly ash consisting of $48.3 \% \mathrm{SiO}_{2}, 25.9 \% \mathrm{Al}_{2} \mathrm{O}_{3}$ was tested by Ulmanu et al. (2007) for immobilizing heavy metals at a strongly contaminated site. The reported chemical compositions of the last two fly ashes imply that the coal or biolites used for combustion purposes could be physically and chemically similar, but different from those considered in our heavy metal inactivation process. 
The framework required for successfully tackling the adsorption - desorption and solubility - precipitation of heavy metals is still a considerable environmental task, due to the fact that their mobility and activity in soils depend on several geochemical factors (Carlon et al. 2000; Basta, McGrowen 2004). Therefore, on the basis of the data from the current study, the reported processes may be synthetically classified as chemical (heavy metal content, $\mathrm{SiO}_{2}, \mathrm{Al}_{2} \mathrm{O}_{3}, \mathrm{Fe}_{2} \mathrm{O}_{3}$ and $\mathrm{CaO}, \mathrm{pH}$ ) and physical (soil and ash particles, surface area). This operational set is reported for two aspects:

- $\quad \mathrm{pH}$ strongly shapes and modifies metal mobility and activity, but this process is only efficient if the total content is significantly high;

- buffering mechanisms are strictly controlled both by the $\mathrm{pH}$ and surface area of organic and mineral particles.

The comparison of fly with bottom ash as undertaken in this study initiates a debate on the challenge faced by soil chemists, when applying these minerals as sorbents. The low specific surface area $\left(\mathrm{SSA}_{\mathrm{EGME}}\right)$ for fly and bottom ashes, i.e. 6.82 and $4.37 \mathrm{~m}^{2} \mathrm{~g}^{-1}$, respectively, do not reflect the high content of $\mathrm{SiO}_{2}$ and $\mathrm{Al}_{2} \mathrm{O}_{3}$; hence, they should not be considered as chemical factors potentially regulating sorption capacities. Similarly, low $\mathrm{SSA}_{\mathrm{BET}}$ (i.e. untreated ash - $2.99 \mathrm{~m}^{2} \mathrm{~g}^{-1}$, and acid-treated ash $-5.41 \mathrm{~m}^{2} \mathrm{~g}^{-1}$ ) values were reported by Bada and Potgieter-Vermaak (2008), as well as by Robl et al. (2010), with a fluidized bed combustion ash of $5.3 \mathrm{~m}^{2} \mathrm{~g}^{-1}$. A strikingly low SSA BET value $\left(0.94 \mathrm{~m}^{2} \mathrm{~g}^{-1}\right)$ was obtained by Ulmanu et al. (2007) in the case of a fly ash investigated for heavy metal immobilization.

The reactivity of ashes investigated in this study, as well as those mentioned above, was characterized by a markedly high inactivation/stabilization efficiency. This process is much more pronounced for ashes where the $\mathrm{CaO}$ levels are relatively high with respect to $\mathrm{SiO}_{2}$. In other words, the higher the $\mathrm{SiO}_{2}$ content the lower the $\mathrm{CaO}$. A similar pattern was observed for the fly and bottom ashes. The content of $\mathrm{CaO}$ and derived compounds could be considered as the master factor responsible for the observed $\mathrm{pH}$ changes (Fig. 1) affecting or controlling heavy metals' inactivation. Therefore, this process could be attributed most practically to the alteration of the physical and chemical parameters of soils, and particularly the $\mathrm{pH}$, as induced by the incorporation of ashes since the $\mathrm{pH}$ was on average 12.3. In their study, Ciccu et al. (2001) also reported a fly ash $\mathrm{pH}$ of 12.2 , similar to that used in the current study. Such strongly alkaline $\mathrm{pH}$ is proof of the high reactivity of ashes, and therefore great care should be taken when applying them to soils, particularly those characterized by weak buffering properties. Some agrochemical opportunities derived from the application of ashes have been outlined (Matsi, Keramidas 1999; Stevens, Dunn 2004).

In a study on the use of fly ash for ameliorating the properties of sandy soils, Właśniewski (2009) indicated that the optimal rate for raising soil fertility and avoiding the threat of heavy metals' input was even $67.2 \mathrm{t} \mathrm{ha}^{-1}$. The fly ash rates beyond $100 \mathrm{t} \mathrm{ha}^{-1}$ decidedly increased heavy metals' content in the soils, even above the standards. In our study, the highest rate equaled to $60 \mathrm{t} \mathrm{ha}^{-1}$ and was found to be optimal for inactivating almost all heavy metals within the contamination degrees I - IV (Table 6), except for $\mathrm{Cu}$, $\mathrm{Zn}$ and $\mathrm{Cd}$ in the case of degree IV. At relatively high soil pH, i.e. 7.5 and beyond, specific adsorption is often the predominant sorptive mechanism (Diatta et al. 2004; Diatta et al. 2012), but chemical sorption and precipitation are much more convincing processes that inactivate the heavy metals. One advantage of mild extractants such as $0.01 \mathrm{~mol} \mathrm{CaCl}_{2} \mathrm{dm}^{-1}$ 
is that they have a limited effect on both the operative $\mathrm{pH}$ at the exchange sites and on complex formation (Carlon et al. 2000). It is a hard task to predict the mobile pool of heavy metals in a natural situation solely on the basis of changes in the extractable fractions after the addition of amendments. Data reported in Table 7 imply that natural attenuation mechanisms were responsible for lowering the concentrations of potentially mobile heavymetal fractions. Such mechanisms were evoked by Bradshaw (2000) and Adriano et al. (2004), and should be considered of prime importance for natural ecosystem reactions against contaminant dissemination to uncontaminated compartments.

The interpretation of these results must take into account the specific properties of heavy metals and particularly their influence on sorption and retention processes, as illustrated by Figure $2-5$. According to Sanderson (1989), the electronegativity values of these metals are 1.65, 1.69, 1.90 and 2.33 for $\mathrm{Zn}, \mathrm{Cd}, \mathrm{Cu}$ and $\mathrm{Pb}$, respectively. This implies, once more, that $\mathrm{Zn}$ and $\mathrm{Cd}$ may be the greatest threat at high soil concentrations, as compared to $\mathrm{Cu}$ and $\mathrm{Pb}$. The inactivation pattern observed for the highest heavy metal loads, i.e. the III and IV contamination degrees, deserves particular consideration. The $\mathrm{pH}$ between the lowest and highest ash rates varied between 5.75 and 6.75 (III degree), as compared to 5.0 and 5.75 recorded for the IV degree. The resulting differences are 1.0 and $0.75 \mathrm{pH}$ units, respectively, and seem relatively low if we take into consideration the $\mathrm{pH}$ of ashes (ca 12.3). Two main factors could have been responsible for this case: i) the dilution process, where the incorporation of ashes into the soils led to the mitigation of their reactivity, and ii) the soil contamination by $\mathrm{CuSO}_{4}, \mathrm{ZnSO}_{4}, \mathrm{~Pb}\left(\mathrm{NO}_{3}\right)_{2}$ and $\mathrm{CdCl}_{2}$ increased the concentrations of acidic anions, i.e. $\mathrm{SO}_{4}{ }^{2-}, \mathrm{NO}_{3}{ }^{-}$and $\mathrm{Cl}^{-}$, efficiently counteracting the $\mathrm{OH}^{-}$from $\mathrm{CaO}$ hydrolyzation. At sites strongly polluted by $\mathrm{M}^{2+} \mathrm{SO}_{4}{ }^{2-}$ compounds ( $\mathrm{M}$ expresses a heavy metal), the efficiency of mineral additives such as lime $(\mathrm{CaO})$ in decreasing heavy metal mobility proceeds as in the case of the current study. Therefore, the highest rates of mineral additives are required to ensure a successful chemical inactivation on the one hand, while also the physical retention of heavy metals throughout the extended buffering properties, for instance, cation exchange capacity (CEC) (Basta, McGrowen 2004; Diatta et al. 2004; Diatta et al. 2012). The high reactivity of ashes, particularly fly ash, may be decidedly mitigated into eco-friendly and beneficial geochemical structures (pH within 5.0 - 7.75 and high heavy metals' buffering mechanisms), which in turn should be favorable conditions for plant growth.

Finally, it should be formulated that the use of fly as well as bottom ashes for inactivation and remediation purposes should intrinsically consider to a greater extent the effect of $\mathrm{pH}$ and the specific physical properties of heavy metals. The rates of ashes and the degree of contamination may only lead to consolidated ash efficiency.

\section{Conclusions}

The data obtained from this study may be summed up as follows:

1) Soil chemical properties altered strongly along with the contamination by heavy metals. These changes were proportional to their rates. The raise in soil acidification expressed by the lowering of $\mathrm{pH}$ impacted $\mathrm{Zn}$ and $\mathrm{Cd}$ retention to a greater extent than $\mathrm{Pb}$ and $\mathrm{Cu}$. 
2) The fly ash fulfilled the condition " $\mathrm{SiO}_{2}>30 \%, \mathrm{Al}_{2} \mathrm{O}_{3}<30 \%$ ", i.e. it is calcic; whereas the bottom ash fitted the range " $\mathrm{SiO}_{2}>40 \%, \mathrm{Al}_{2} \mathrm{O}_{3}<30 \%$ ", and thus is siliceous. The calcic form exhibited the highest reactivity with respect to the siliceous bottom ash.

3) For the moderately contaminated treatments (I and II), the rates $0.25,0.5$ and $1 \%$ of both ashes were found to be highly efficient for inactivating $\mathrm{Cu}, \mathrm{Zn}, \mathrm{Pb}$ and $\mathrm{Cd}$, with $\mathrm{Pb}$ and $\mathrm{Cu}$ to a greater extent than $\mathrm{Cd}$ and $\mathrm{Zn}$. This efficiency ranged from 40 to $70 \%$ for $\mathrm{Zn}$ and $\mathrm{Cd}$, but raised markedly to between 60 and $93 \%$ for $\mathrm{Cu}$ and $\mathrm{Pb}$, as compared to the control treatment.

4) In the case of the extremely contaminated treatments (III and IV), the rates of both ashes 1.0 and $2.0 \%$ were much more efficient in the inactivation of all metals, at nearly $60-80 \%$.

5) The use of fly and bottom ashes for metal inactivation and remediation purposes should give greater consideration to the effect of $\mathrm{pH}$ (regulated by the levels of $\mathrm{CaO}$ ) and the type of heavy metals than the content of $\mathrm{SiO}_{2}$ and $\mathrm{Al}_{2} \mathrm{O}_{3}$. The fly ash displayed best inactivation and remediation effects to the bottom ash.

\section{References}

Adriano, D. C., Wenzel, W. W., Vangronsveld, J., \& Bolan, N. S. (2004). Role of assisted natural remediation in environmental cleanup. Geoderma, 122, 121-142. DOI: 10.1016/j.geoderma.2004.01.003.

Antonkiewicz, J. (2007). Influence of different ash-sludge and ash-peat mixtures on the yield and elements content of a grass and birdsfoot trefoil mixted stand. Part II. Heavy metals. Zeszyty Problemów Postępów Nauk Rolniczych, 520, 265-278 [in Polish].

Bada, S. O., \& Potgieter-Vermaak, S. (2008). Evaluation and treatment of coal fly ash for adsorption application. Leonardo Electronic Journal of Practices and Technologies, 12, 37-48.

Barrow, N. J. (1999). The four laws of soil chemistry: The Lepper lecture 1998. Australian Journal of Soil Research 37, 787-829.

Basta, N. T., \& McGowen, S. L. (2004). Evaluation of chemical immobilization treatments for reducing heavy metal transport in a smelter-contaminated soil. Environmental Pollution, 127, 3-82. DOI: 10.1016/S02697491(03)00250-1.

Brunauer, S., Emmett, P. H., \& Teller, E. (1938). Adsorption of gases in multimolecular layers. Journal of American Chemical Society 60, 309-319. DOI: 10.1021/ja01269a023.

Bradshaw, A. (2000). The use of natural processes in reclamation - Advantages and Difficulties. Landscape and Urban Planning, 51(2-4), 89-100. DOI: 10.1016/S0169-2046(00)00099-2.

Carlon, C., Norbiato, M., Critto, A., \& Marcomini, A. (2000). Risk analysis applied to a contaminated industrial site: Determination of risk based remedial targets. Annale Chimica, 90, 349-358.

Carter, D. L., Mortland, M. M., \& Kemper, W. D. (1986). Specific Surface. Methods of Soil Analysis. Chapter 16, Agronomy, No. 9, Part 1, $2^{\text {nd }}$ Ed., American Society of Agronomy.

Ciccu, R., Ghiani M., Peretti, R., Serci A., \& Zucca A. (2001). Heavy metal immobilisation using fly ash in soil contaminated by mine activity. International Ash Utilization Symposium. Center for Applied Energy Research, University of Kentucky. Paper \#6 (www.flyash.info).

Circular Economy Package (CEP): http://ec.europa.eu/environment/circular-economy (Entry 15.07.2017)

de Jong, E. (1999). Comparison of three methods of measuring surface area of soils. Canadian Journal of Soil Science 79, 345-351. DOI: 10.4141/S98-069.

Diatta, J. B., Grzebisz, W., \& Wiatrowska, K. (2004). Competitivity, selectivity, and heavy metals-induced alkaline cation displacement in soils. Soil Science and Plant Nutrition, 50(6), 899-908. DOI: 10.1080/00380768.2004.10408552.

Diatta, J. B., Grzebisz, W., \& Wiatrowska, K. (2007). Assessment of copper and zinc stabilization process in soils after the application of brown coal, sugar beet leaves and cement. Ecological Chemistry and Engineering, 14(2),181-189.

Diatta, J. B., \& Chudzińska, E. (2009). Chemical remediation of zinc contaminated soils by applying a cementbrown coal-based component (CEMBRO). Ochrona Środowiska i Zasobów Naturalnych, 41, 89-101. 
Diatta, J. B., Skubiszewska, A., \& Witczak R. (2009). Assessment of chemical degradation of selected soil properties as induced by copper, zinc and hydrogen. Ecological Chemistry and Engineering A, 16, 1-10.

Diatta, J. B., Komisarek, J., \& Wiatrowska, K. (2012). Evaluation of heavy metals competitive sorption and potential mobility on the basis of $\mathrm{Cu} / \mathrm{Cd}$ and $\mathrm{Zn} / \mathrm{Pb}$ binary systems. Fresenius Environmental Bulletin, 21(5), 1105-1109.

Fotovat, A., Naidu, R., \& Sumner M. E. (1997). Water: soil ratio influences aqueous phase chemistry of indigenous copper and zinc in soils. Australian Journal of Soil Research 35, 687-709. DOI: 10.1071/S96086.

Gajda, A., Jaworski W., \& Barc W. (2002). Prognosis in the production of coal combustion by-products at professional power stations to 2015. Biuletyn Miesięczny PSE SA, 11(137), 2-14 [in Polish].

Gluzińska, J. Walawska B., \& Łuczkowska D. (2016). Properties of waste fly ash as a hard coal combustion byproduct after the application of dry sodium sorbents to purify flue gases. Prace Instytutu Mechaniki Górotworu PAN, 18(3), 83-91 [in Polish].

Gregg, S. J., \& Sing, K. S. W. (1967). Adsorption, Surface Area and Porosity. Academic Press Inc, London, UK, p. $44-50$.

Gupta, S. K., Herren, T., Wenger, K., Krebs, R., \& Hari, T. (2000). In-situ gentle remediation measures for heavy metal-polluted soils, [in:] Phytoremediation of contaminated soil and water. Soil and Water Pollution, CRC Press LLC, p. 303-322.

Hycnar, J. J., Szczygielski, T., Lysek, N., \& Rajczyk, K. (2014). Trends in the optimalisation of the management of coal combustion by-products. Piece Przemystowe i Kotty, 5-6,16-27 [in Polish].

Ibekwe, A. M, Angle, J. S, Chaney, R. L, \& Van Berkum, P. (1997). Enumeration and $\mathrm{N}_{2}$ fixation potential of Rhizobium leguminosarum biovar trifolii grown in soil with varying $\mathrm{pH}$ values and heavy metal concentrations. Agriculture Ecosystems and Environment 61,1679-1685.

International Standard (1995). Soil quality - Extraction of trace elements soluble in aqua regia, ISO 11466 Geneva.

Kabata-Pendias, A., Motowicka-Terelak, T., Piotrowska, M., Terelak, H., \& Witek, T. (1993). Evaluation of the degree of soils and plants contamination by heavy metals and sulphur. Framework guidelines for agriculture. IUNG Puławy $\mathrm{P}(53), 20$ p. (in Polish).

Krebs, R., Gupta, S. K., Furrer, \& Schulin, G. R. (1999). Gravel sludge as immobilizing agent in soils contaminated by heavy metals: a field study. Water, Air and Soil Pollution, 115, 465-479. DOI: 10.1023/A:1005167004828.

Kumpiene, J., Lagerkvist A., \& Maurice C. (2008). Stabilization of $\mathrm{As}, \mathrm{Cr}, \mathrm{Cu}, \mathrm{Pb}$ and $\mathrm{Zn}$ in soil using amendments - A review. Waste Management 28, 215-225. DOI: 10.1016/j.wasman.2006.12.012.

Lombi, E., Hamon, R. E., McGrath, S. P. \& Mc-Laughlin, M. J. (2003). Lability of Cd, Cu and Zn in polluted soils treated with lime, beringite, and red mud and identification of a non-labile colloidal fraction of metals using isotopic techniques. Environmental Science and Technology, 37(5), 979-984. DOI: 10.1021/es026083w.

Łączny, M. J. (2002). Non-conventional method of utilization of fly ash. Central Mining Institute, Katowice, pp. 7-19.

Matsi, T. \& Keramidas, V. Z. (1999). Fly ash application on two acid soils and its effect on soil salinity, pH, B, P and ryegrass growth and composition. Environmental Pollution, 104(1), 107-112. DOI: 10.1016/S02697491(98)00145-6.

McBride, M. B., Sauvé, S., \& Hendershot W. (1997). Solubility control of $\mathrm{Cu}, \mathrm{Zn}, \mathrm{Cd}$ and $\mathrm{Pb}$ in contaminated soils. European Journal of Soil Science, 48, 337-346. DOI: 10.1111/j.1365-2389.1997.tb00554.x.

McGowen, S. L. (2000). In-situ chemical treatments for reducing metal solubility and transport in smelter contaminated soils. Ph.D. Diss. Dep. Plant and Soil Sciences, Oklahoma State Univ., Stillwater, OK.

Mench, M., Vangronsveld, J., Lepp, N. W., \& Edwards, R. (1998). Physicochemical aspects and efficiency of trace element immobilization by soil amendments. In: J. Vangronsveld and S. D. Cunningham (editors): Metal-Contaminated Soils: In-situ inactivation and phytorestoration, pp. 151-182. Springer Verlag, Berlin Heidelberg. ISBN: 1-57059-531-3.

Mohapatra, R., \& Rao, J. R. (2001). Some aspects of characterisation, utilisation and environmental effects of fly ash (a Review). Journal of Chemical Technology and Biotechnology, 76(1), 9-26. DOI: 10.1002/10974660(200101)76:1<9::AID-JCTB335>3.0.CO;2-5.

Oste, L. A., Lexmond, T. M. \& Van Riemsdijk, W. H. (2002). Metal immobilization in soils using synthetic zeolites. Journal of Environmental Quality, 31(3), 813-821.

Percival, H. J, Speir, T. W, \& Parshotam, A. (1999). Soil solution chemistry of contrasting soils amended with heavy metals. Australian Journal of Soil Research 37, 993-1004. DOI: 10.1071/SR98055. 
Polish Standard (1994). Polish Standardisation Committee, ref. PrPN-ISO 10390 (E): Soil quality and pH determination. First edition (in Polish).

Querol, A. A., Moreno, N., Alvarez-Ayuso, E., García-Sánchez, A., Cama, J., Ayora, C. \& Simón, M. (2005). Immobilization of heavy metals in polluted soils by the addition of zeolitic material synthesized from coal fly ash. Chemosphere, 62(2), 171-180. DOI: 10.1016/j.chemosphere.2005.05.029.

Ramme, B. W., \& Tharaniyil, M. P. (2013). We Energies - Coal Combustion Products Utilization Handbook. Copyright 2013, Wisconsin Electric Power Company. $3^{\text {rd }}$ Edition, Manufactured in the United States of America, $448 \mathrm{p}$.

Rhoades, J. D. (1996). Salinity: Electrical conductivity and total dissolved solids. In: Sparks D.L. et al. (ed). Methods of soil analysis. Part 3. SSSA Book Ser. 5. SSSA, Madison, WI, 417-435.

Robl, T., Mahboub, K., Will, S., \& Robert R. (2010). Fluidized bed combustion ash utilization: CFBC fly ash as a pozzolanic additive to Portland cement concrete. Coventry University and the University of Wisconsin Milwaukee Centre for By-products Utilization. Second International Conference on Sustainable Construction Materials and Technologies (June 28-30, 2010). Universita Politecnica delle Marche, Ancona, Italy. Special Technical Proceedings ed. Claisse, P., Ganjian, E., Canpolat, F., \& Naik, T. (ISBN 978-1-4507-1488-4).

Sanderson, R. (1989). Electronegativity and bond energy. Journal of American Chemical Society, 105(8), 22592261.

Sarbak, Z., \& Kramer-Wachowiak, M., 2012: The use of fly ash as sorbents for heavy metals. Przemyst Chemiczny, 91(2), 189-192 [in Polish].

Schutter, M. E., \& Fuhrmann, J. J. (2001). Soil microbial community responses to fly ash amendment as revealed by analyses of whole soils and bacterial isolates. Soil Biology and Biochemistry 33(14), 1947-1958.

Singh, S. D. C. \& Shea, P. J. (1999). Iron-mediated remediation of RDX-contaminated water and soil under controlled Eh/pH. Environmental Science and Technology, 33(9), 1488-1494. DOI: 10.1021/es9806175.

Sparks, D. L. (1995). Environmental soil chemistry. Academic Press Inc. San Diego, California: 267 p.

Stevens, G., \& Dunn, D. (2004). Fly ash as a liming material for cotton. Journal of Environmental Quality, 33(1), 343-348. DOI: 10.2134 jeq2004.0343.

Szymańska, I. (2013). Combustion By-Products - waste, product, raw material. www.surowiec-naturalne.pl [in Polish]

Tandy, S., Bossart, K., Mueller, R., Ritschel, J., Hauser, L., Schulin, R. \& Nowack, B., (2004). Extraction of heavy metals from soils using biodegradable chelating agents. Environmental Science and Technology, 38(3), 937-944. DOI: 10.1021/es0348750.

Thomas, G.W. (1982): Exchangeable cations. (p. 159-165). Methods of Soil Analysis, Part 2. Chemical and Microbial Properties (No. 9), ASA-SSSA. Second Edition. Edited by Page A. L., Miller, R. H. \& Keeney D.R. Madison, Wisconsin, USA

Terzano, R., Spagnuolo, M., Medici, L., \& Ruggiero, P. (2004). Stabilization of Cu and Cd in the presence of montmorillonite by means of coal fly ash. Fresenius Environmental Bulletin 13(10), 995-999.

Ulmanu, M., Matsi, T., Anger, I., Gament, E., Olanescu, G., Predescu, C., Sohaciu, M. (2007). The remedial treatment of soil polluted with heavy metals using fly ash. University Politehnica București Scientific Bulletin $B / 69(2), 109-116$.

Wei, Y. L., Yang, Y. W. \& Cheng, N. (2001). Study of thermally immobilized Cu in analogue minerals of contaminated soils. Environmental Science and Technology, 35(2), 416-421. DOI: 10.1021/es0008721.

Właśniewski, S. (2009). Effect of fertilization with fly ash from black coal on some chemical properties of sandy soil and yields of oat. Ochrona Środowiska i Zasobów Naturalnych, 41, 479-488.

Xiao, R., Chen, X., Wang, F., \& Yu, G. (2011). The physicochemical properties of different biomass ashes at different ashing temperature. Renewable Energy 36, 244-249. DOI: 10.1016/j.renene.2010.06.027. 